\title{
The effect of particle size distribution on froth stability in flotation
}

\author{
A. Norori-McCormac, P.R. Brito-Parada, K. Hadler*, K. Cole \& J.J. Cilliers \\ Department of Earth Science and Engineering, Imperial College London, SW7 2AZ, United \\ Kingdom.
}

*Corresponding author can be contacted at k.hadler@imperial.ac.uk

\begin{abstract}
Separation of particles of different surface properties using froth flotation is a widely-used industrial process, particularly in the minerals industry where it is used to concentrate minerals from ore. One of the key challenges in developing models to predict flotation performance is the interdependent nature of the process variables and operating parameters, which limits the application of optimising process control strategies at industrial scale. Froth stability, which can be quantified using air recovery (the fraction of air entering a flotation cell that overflows in the concentrate as unburst bubbles), has been shown to be linked to flotation separation performance, with stable froths yielding improved mineral recoveries. While it is widely acknowledged that there is an optimum particle size range for collection of particles in the pulp phase, the role of particle size on the measured air recovery and the resulting link to changes in flotation performance is less well understood. This is related to the difficulty in separating particle size and liberation effects.
\end{abstract}

In this work, the effects of particle size distribution on air recovery are studied in a single species (silica) system using a continuous steady-state laboratory flotation cell. This allows an investigation into the effects of particle size distribution only on froth stability, using solids content and solids recovery as indicators of flotation performance. It is shown that, as the cell air rate is increased, the air recovery of the silica system passes through a peak, exhibiting the same froth behaviour as measured industrially. The air recovery profiles of systems with three different particle size distributions ( $d_{80}$ of 89.6, 103.5 and $157.1 \mu \mathrm{m}$ ) are compared. The results show that, at lower air rates, the intermediate particle size distribution $(103.5 \mu \mathrm{m})$ yields the most stable froth, while at higher air rates, the finest particles $(89.6 \mu \mathrm{m})$ result in higher air recoveries. This is subsequently linked to changes in flotation performance. The results presented here highlight, for the first time, the link between particle size distribution in flotation feeds, air recovery and flotation performance. The results demonstrate that there is an optimal air rate for each particle size distribution, therefore changes in particle size distribution in the feed to flotation cells require a change in air rate in order to maximise mineral recovery.

\section{Keywords}

Froth flotation, froth stability, particle size, air recovery, flotation performance

\section{Introduction}

Froth flotation is a complex and widely used separation technique, which relies on differences in the surface properties of the desired particles to the unwanted particles. One of the key parameters in flotation is the particle size distribution of the feed and it has been 
shown in several studies that the optimal size range for flotation is relatively narrow, approximately $20-150 \mu \mathrm{m}$ (Gaudin et al., 1942; Jameson et al., 2007). Particle hydrophobicity and contact angle (in addition to hydrodynamic factors) determine the attachment of particles to bubbles in the pulp, which in turn affects the froth stability (Klassen and Mokrousov, 1963; Johansson and Pugh, 1992).There remains much debate, however, on the effect of particle size on froth stability.

Johansson and Pugh (1992) found that, with small quartz particles ( $26-44 \mu \mathrm{m})$, the stability of the froth was maximised at an intermediate degree of hydrophobicity. Rahman et al. (2012) indicated that fine particles increase froth stability and impede coalescence through increasing the rigidity of the bubble films in a specialised agitated column, a finding additionally demonstrated by Ata (2011). Furthermore, Aktas et al. (2008) demonstrated with a platinum ore in a lab based study that particle size had a significant effect on froth stability with fine particles of approximately $30-40 \mu \mathrm{m}$ increasing froth stability at low air rates. Conversely, Tao et al. (2000) observed that coal particles of less than $30 \mu \mathrm{m}$ diameter destabilised the froth in a laboratory based flotation column

Similarly, there is no general agreement on the effect of coarse particles on froth stability. Livshits and Dudenkov (1965) suggested that their presence retarded film coalescence in the froth phase, improving stability, whereas Moudgil (1992) indicated that there is a tendency for coarse particles to rupture the thin films of bubbles, resulting in particles detaching and draining back into the froth phase. Yianatos et al. (2009) demonstrated that coarse particle entrainment is insignificant using radioactive tracers in an industrial flotation cell, implying attachment is the dominant mechanism of recovery. Separately, Zheng et al. (2006) indicated that coarse particles recovered at low air rates may be recovered through entrapment, their presence under specific operating conditions otherwise unexplained as they should settle out of the froth phase.

Recently, Liang et al. (2015) showed that varying the hydrophobicity and proportion of fine coal particles affects their ability to stabilise the froth. An intermediate particle size of $74-$ $250 \mu \mathrm{m}$ resulted in the deepest and most stable froths. When a mixture of particle sizes was considered, a combination of approximately $55 \%$ fines $-74 \mu \mathrm{m}$ with $45 \%$ coarse particles at $250-500 \mu \mathrm{m}$ resulted in the greatest recovery of coal to the concentrate.

While the effect of particle size on froth stability and flotation performance has been the focus of much research, the literature is contradictory on whether fine particles stabilise or destabilise flotation froths from a physics-based perspective (i.e. negating liberation and surface chemistry effects). Many tests have been carried out using static froth column experimental systems to measure froth stability (e.g. Falutsu, 1994; Tao et al., 2000; Barbian et al., 2006), however there are few reported studies into particle size effects on froth stability for a flowing flotation froth. This is due, in part, to the difficulty in decoupling particle size and liberation effects. 
For continuous flotation systems, dynamic froth stability can be quantified using air recovery, $\alpha$,as defined in Equation 1:

$$
\alpha=\frac{v_{f} h_{w} L}{Q_{a}},
$$

where $Q_{a}$ is the air flowrate into the cell, $v_{f}$ the froth velocity as it overflows the lip, $h_{w}$ the height of the froth above the lip and $L$ is the lip length of the flotation cell. Hadler \& Cilliers (2009) noted that increasing air rate leads to a peak in air recovery (PAR), and this corresponds with a peak in the recovery of mineral to the concentrate. Furthermore, Hadler et al. (2010) demonstrated that operating at PAR resulted in optimal recovery in banks of flotation cells, describing the changes as being related to changes in particle loading on bubbles, bubble stability and froth mobility. This was further demonstrated by Smith et al. (2010).

Air recovery and peak air recovery (PAR) were also affected by variations in operating parameters such as froth depth. Hadler et al. (2012) showed that air recovery passed through a peak with increasing froth depth at a constant air rate, or conversely that the PAR air rate for shallow froths is lower than that for deep froths.

There have been few studies considering particle size effects on froth stability in industrial flotation cells. One study by Tasdemir et al. (2007) considered the effect of variation in operating parameters on particle size in a Jameson cell, with increasing concentrate flowrate associated with increased coarse particle recovery, and an increased jet length and velocity resulting in the increase of fine particle recovery at the expense of coarse particles. One of the challenges of investigating the effect of particle size at industrial scale is that there is typically little control over the feed particle size, with fluctuations being driven by changes in the milling circuit. To this end, in this study, a continuous steady-state bench-scale flotation system has been developed.

Bench-scale experiments are critical to developing an understanding of the fundamental processes that govern froth flotation at the micro and macro scale. Standard laboratory batch flotation tests are limited, however, by the lack of steady-state operation. The benefits of a continuous laboratory flotation system are that the effect of individual operating parameters can be investigated. However, operating such a system over a long period of time with a real ore presents a challenge. Ores are heterogeneous and mineral liberation varies, which can result in a lack of consistency in operational performance within and between experiments.

Several authors have previously developed semi-continuous systems based on batch flotation cells. Kaya and Laplante (1985) modified a Denver cell, introducing a continuous feed of milled copper ore to allow for extended operation at steady-state to investigate entrainment at a range of air rates, although the total operating time of the system is not specified. Cornell et al. (1987) continuously fed circuits of batch test cells with feed 
containing cobalt in order to optimise recovery. Vera et al. (2002) made use of a benchscale Leeds cell in both batch and continuous modes, with continuous operation of up to 5 minutes, however the system was difficult to control, was not representative of true flotation cell design, and did not eliminate the issues relating to control of particle size and mineral liberation, making comparisons between tests more difficult. An alternative approach is that of Welsby et al. (2010), where a continuous flotation system was developed using 5, 20 and $40 \mathrm{~L}$ cells, using feed from a plant, which was held in three $230 \mathrm{~L}$ sumps. While this reduces the effects of feed variability, it does not allow the systematic investigation of particle size effects explicitly. Other laboratory flotation systems that operate continuously have been developed by Brito-Parada and Cilliers (2012) and Shean et al. (2017). The former used a $50 \mathrm{~L}$ flotation tank with continuous recycle to test different overflowing and launder configurations while, more recently, Shean et al. (2017) developed a continuous $70 \mathrm{~L}$ laboratory flotation cell with the objective of developing and optimising a flotation control system based on peak air recovery; however these systems were two phase (surfactant solution and air) only.

While previous studies have investigated the effect of particle size distribution for specific mineral systems, or at constant air rate, in this study the objective is to develop an understanding of the interrelationship between particle size distribution, cell air rate and the resulting effect on froth stability (measured using air recovery). This will have important implications for the optimisation of flotation separation performance, particularly with regards to process control. To this end, a continuous steady state laboratory system, exhibiting particle-stabilised froth behaviour that is typical of industrial flotation cells has been developed. A single species (silica) system is used in order to remove liberation and/or oxidation effects and to enable continuous stable operation over a period of time.

\section{Methodology}

\subsection{Experimental system}

The experimental system is a $4 \mathrm{~L}$ closed loop, continuously overflowing bench-scale flotation cell. The continuous recycle of concentrate as feed to the cell allows for steady state conditions to be established. The design of the cell is based upon the standard mixing tank by Costes \& Couderc (1988).

The cell is cylindrical and has an internal diameter of $180 \mathrm{~mm}$. It is of equal width and height, stirred by a six bladed Rushton impeller connected via a 2:1 rpm ratio stepped gearbox (supplied by Automation International Ltd) to the motor, supplied by Marelli Motori. Four baffles are installed to a height of $120 \mathrm{~mm}$ at $90^{\circ}$ intervals. At the base is an air reservoir, separated from the cell by a frit (manufactured by Carbis Filtration Ltd), $110 \mathrm{~mm}$ in diameter and $1.3 \mathrm{~mm}$ in thickness, centred below the impeller. The frit has a mesh hole-size of 20 $\mu \mathrm{m}$, fabricated from multiple sintered layers. Attached to the exterior of the cell is a launder, 
angled at $10^{\circ}$ from back to front that has a width of $60 \mathrm{~mm}$. The experimental system is shown in Figure 1.
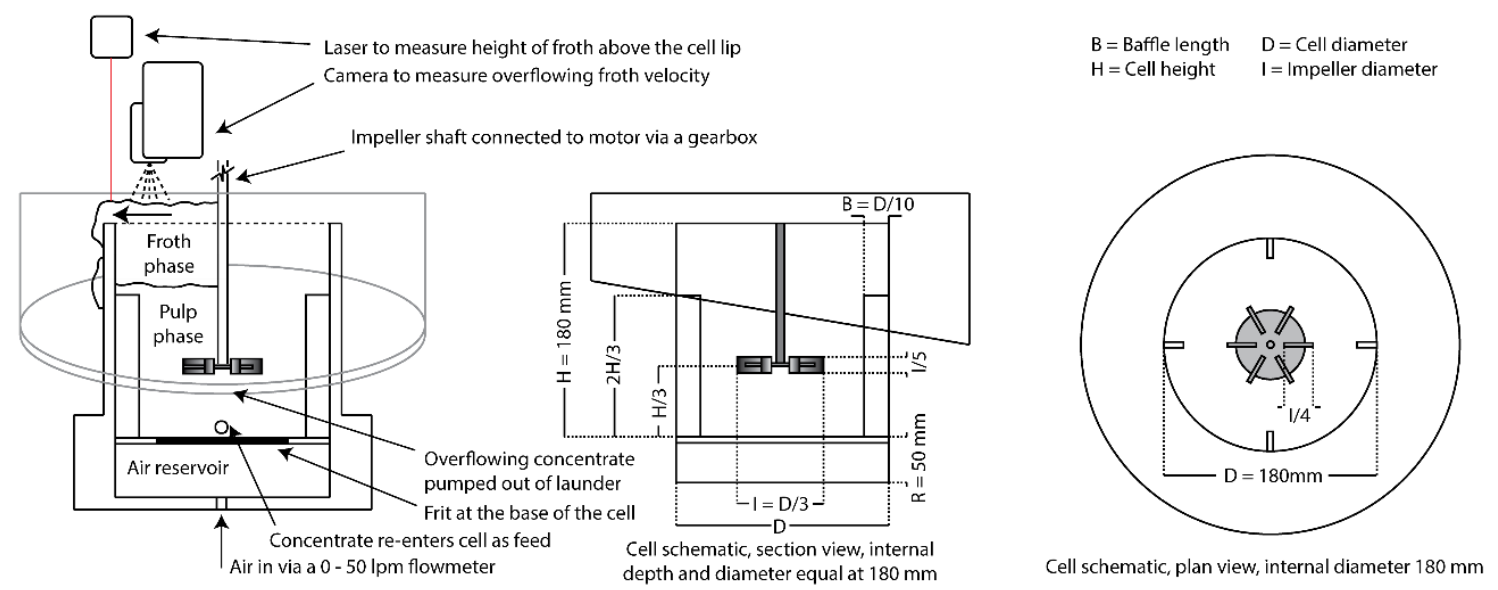

Figure 1 - Schematic of the bench-scale flotation cell

A single species system is described in this paper; this can be used to determine the effects of changing operating variables, for example air rate, into the flotation cell. Spherical silica ballotini for the experiments were supplied by Sigmund Lindner. Pre-sized distributions were sourced with ranges from $40-70 \mu \mathrm{m}, 70-110 \mu \mathrm{m}$ and $90-150 \mu \mathrm{m}$. Three particle sets were created by mixing the pre-sized material, obtaining the particle size distributions presented in Figure 2. Representative diameters for the three particle sets are shown in Table 1, where it can be seen that particle set $A$ has the coarsest particles and the broadest size distribution while particle set $\mathrm{C}$ is the finest of the three. This allows investigation into the effects of relatively small variation in particle size distribution on air recovery and flotation performance. 


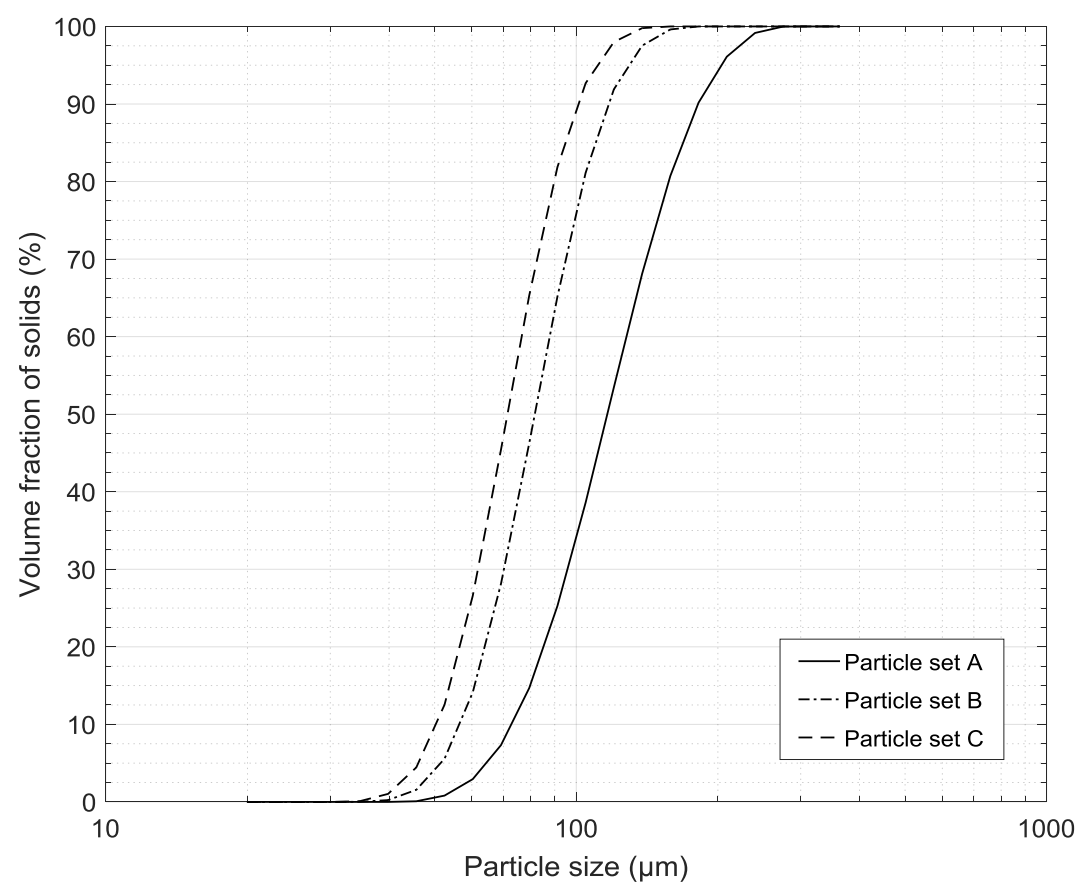

Figure 2 - Cumulative particle size distributions for the particle sets considered in this paper

Table 1 - Particle size for the particle sets considered in this paper.

\begin{tabular}{|c|c|c|c|}
\hline \multirow{2}{*}{$\begin{array}{c}\text { Characteristic } \\
\text { diameter }(\boldsymbol{\mu m})\end{array}$} & \multicolumn{3}{|c|}{ Particle set } \\
\cline { 2 - 4 } & A & B & C \\
\hline $\mathrm{d}_{10}$ & 73.3 & 57.0 & 50.7 \\
\hline $\mathrm{d}_{50}$ & 116.5 & 81.6 & 71.4 \\
\hline $\mathrm{d}_{80}$ & 157.1 & 103.5 & 89.6 \\
\hline
\end{tabular}

For each experiment, $900 \mathrm{~g}$ of ballotini were used. The ballotini were initially prepared by mixing with 2 litres of $5 \times 10^{-4} \mathrm{M}$ sodium hydroxide solution, based on a similar preparation procedure as set out by Ata et al. (2002). This was undertaken to strip the ballotini surfaces of impurities. The ballotini were washed with deionized water and then mixed with $2.9 \mathrm{~L}$ of deionized water to form a slurry with a pulp $\mathrm{pH}$ of 7.9 in suspension. The collector, Tetradecyltrimethylammonium bromide (TTAB), was added at a concentration of $278.4 \mathrm{ppb}$. The slurry was then allowed to mix at $915 \mathrm{~Hz}$ for 30 minutes. Methyl isobutyl carbinol (MIBC) was then added at $352 \mathrm{ppm}$, and the slurry allowed to mix for a further 5 minutes.

Air rates for the experiments were selected from a range between 10 and $30 \mathrm{lpm}$ (litres per minute) as shown in Table 2. This range corresponds to superficial gas velocities of 0.66 $1.97 \mathrm{~cm} \mathrm{~s}^{-1}$. A further 15 minutes of conditioning was then allowed with the froth overflowing before the first air rate was selected. At this time, dosing started with additional MIBC at a rate of $4.2 \mathrm{ml} \mathrm{h}^{-1}$ of $102 \mathrm{ppm}$ MIBC solution to maintain froth stability. Froth depth (from cell 
lip to pulp-froth interface) was maintained at $7.5 \mathrm{~cm}$ by adjusting the recycle pump as required.

Table 2 - Air rates and the equivalent superficial gas velocities $(\mathrm{Jg})$ investigated in this paper.

\begin{tabular}{|c|c|}
\hline Air rate (lpm) & $\mathbf{J g} \mathbf{~ ( c m ~ s}^{\mathbf{- 1}}$ ) \\
\hline 10 & 0.66 \\
\hline 15 & 0.98 \\
\hline 20 & 1.31 \\
\hline 25 & 1.64 \\
\hline 30 & 1.97 \\
\hline
\end{tabular}

\subsection{Measurement}

For each air rate, 5 minutes of conditioning was allowed, before 5 minutes of on-line data collection. The height of the overflowing froth above the lip of the cell was measured via an on-line laser (0D1300, supplied by ifm electronic) and the data recorded through LabVIEW (National Instruments, 2016). The velocity of the overflowing froth was measured using a camcorder (Panasonic Video NVGS37) through FrothTracker, a block-matching image analysis program developed in-house. The output values were then used to calculate air recovery using Equation 1.

In order to sample the concentrate, a scoop was fitted to the lip of the flotation cell for $20 \mathrm{~s}$ at the end of each measurement period. The sample was weighed, and the mass of the solid and liquid phases determined by decanting the liquid into a measuring cylinder. The sample was then returned to the launder. Only one sample was taken for each air rate tested, as removing too much of the concentrate leads to a destabilisation of the experimental system.

\section{Results and discussion}

\subsection{Steady State Verification}

In order to establish the stability of the flotation system when operating continuously, a test was carried out under conditions of constant air rate $\left(\mathrm{Jg}=1.31 \mathrm{~cm} \mathrm{~s}^{-1}\right)$ over a period of 90 minutes. For this test, particle set $A\left(d_{80} 157.1 \mu \mathrm{m}\right)$ was used. The variation in froth velocity, froth overflowing height and air recovery can be seen in Figure 3. It should be noted that these data correspond to 5 second average values. 

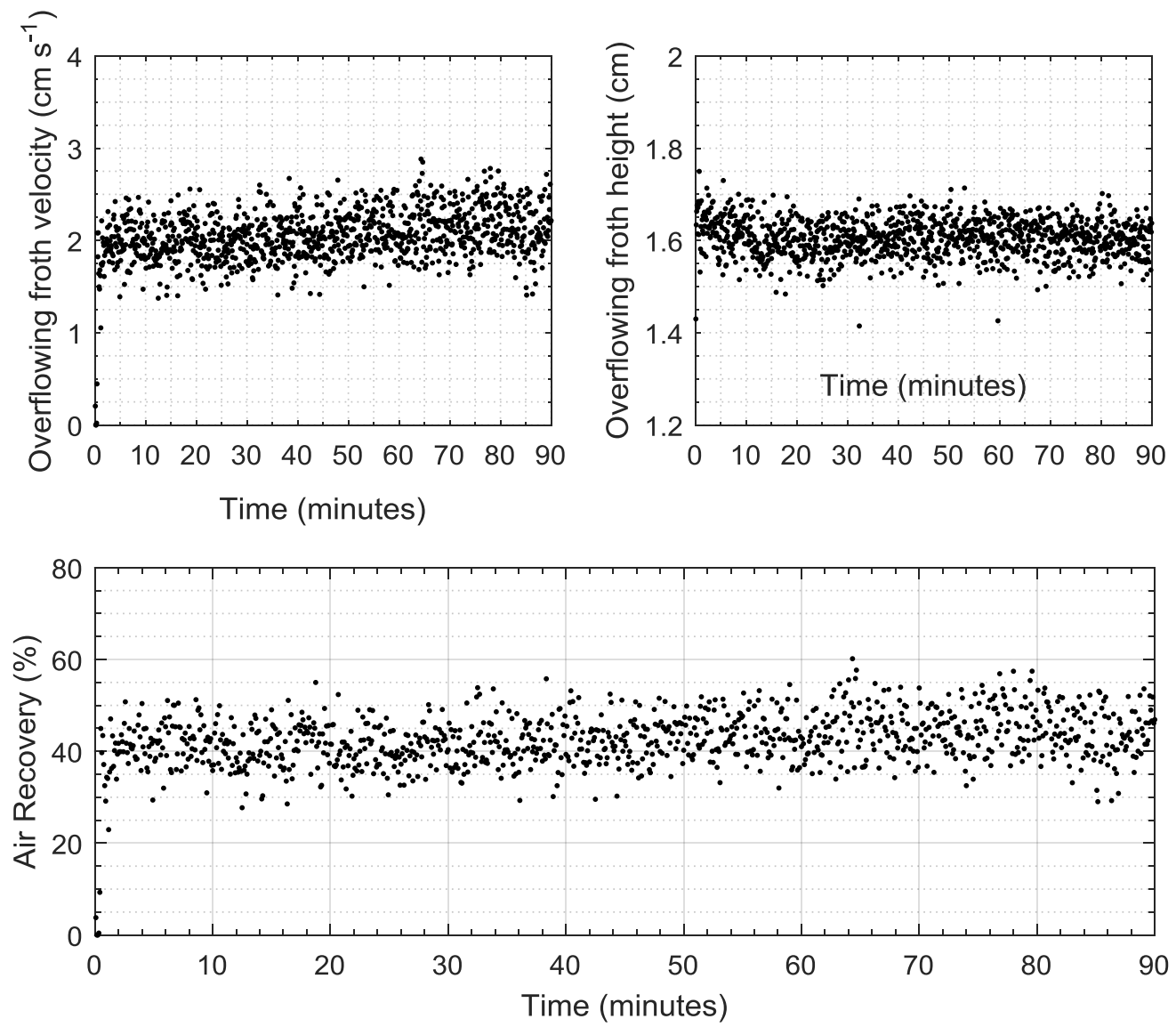

Figure 3 - Five second average of (a) froth velocity, (b) overflowing froth height and (c) air recovery with time for the experimental system at a Jg of $1.31 \mathrm{~cm} \mathrm{~s}^{-1}$, indicating the system is operating at steady state.

The results show that, over the course of the experiment, the froth velocity and overflowing froth height remained stable. The overflowing froth height can be observed to drop to a stable value over the initial 5 minutes of the run, whereas froth velocity increases to a stable value in the first 5 minutes. This is linked to a period of transition before steady state is established. For this reason, following an air rate change in subsequent experiments, 5 minutes were allowed for steady state to be reached. It is also noted that over the course of the test, average froth velocity increased by approximately $0.05 \mathrm{~cm} \mathrm{~s}^{-1}$; this is likely to be linked to the continual dosing of MIBC through the test.

Disregarding the initial 5 minutes of data, over the remaining 85 minutes, the $95 \%$ confidence intervals for the froth velocity and overflowing froth height were $\pm 0.15 \mathrm{~cm} \mathrm{~s}^{-1}$ and $\pm 0.04 \mathrm{~cm}$ respectively. Air recovery has an average value of $43.8 \%$ with a $95 \%$ confidence interval of $\pm 3.1 \%$.

\subsection{Air Recovery Characterisation}


The response of the measured air recovery with variation in air rate for particle set $A\left(d_{80}\right.$ $157.1 \mu \mathrm{m}$ ) is shown in Figure 4 (a). Following 5 minutes of stabilisation time, a further 15 minutes of steady state operation was allowed at each air rate; the error bars represent the $95 \%$ confidence interval of the air recovery over this time period. From Figure 4 (a) it can be seen that the laboratory flotation system passes through a peak in air recovery as the air rate is increased. This reflects trends measured industrially, as shown in Figure 4 (b) for a single cell, taken from the down the bank data presented in Hadler and Cilliers (2009). This demonstrates the applicability of the system for the investigation of particle size effects.

While the laboratory system comprises a single species, the existence of a peak in air recovery suggests that, over the range of air rates tested, the froth was particle stabilised. At low air rates, lower bubble surface area fluxes allow for higher particle loading in the pulp phase. The bubbles arriving into the froth are stabilised by the particles, however longer froth residence times and lower entrainment of water and unattached particles yield a froth with low mobility and consequently lower air recovery (i.e. more bubble bursting). At high air rates, the opposite occurs, with higher froth mobility due to an increase in liquid content, but low particle loadings resulting in more bursting. At the PAR air rate, the optimal combination of bubble loading and froth mobility occurs. This is not affected by the presence of only a single species for this particle size distribution.
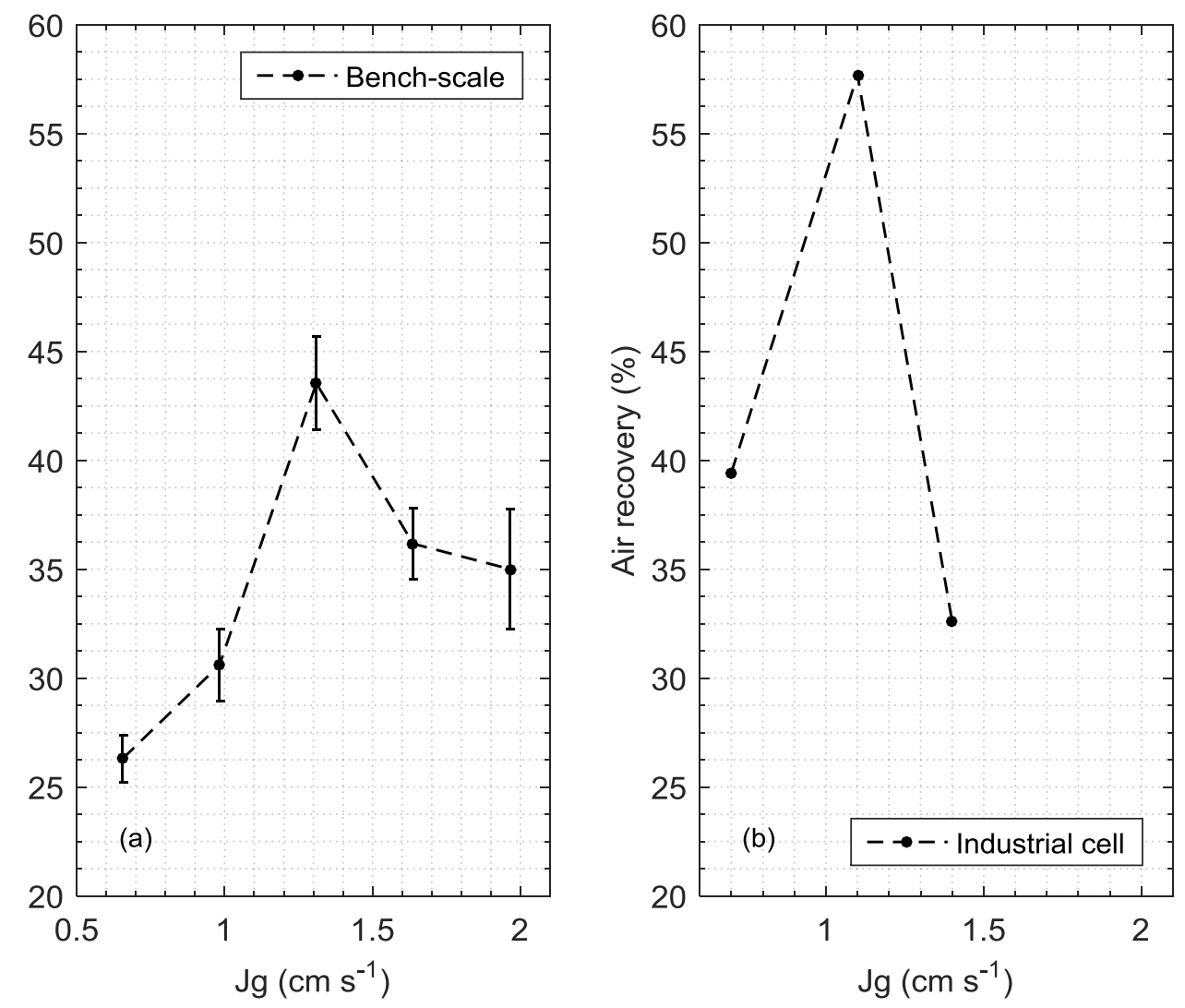

Figure 4 - (a) Air recovery for the bench-scale system compared with (b), air recovery as a function of Jg for an industrial flotation cell (Hadler and Cilliers, 2009). Errors given as $95 \%$ confidence intervals. 


\subsection{The effect of particle size on air recovery}

The variation in air recovery for the three particle sets over a range of air rates is shown in Figure 5. Data obtained at the higher air rates of 1.64 and $1.97 \mathrm{~cm} \mathrm{~s}^{-1}$ are not shown. For the finer size distributions (particle sets $\mathrm{B}$ and $\mathrm{C}$ ), at higher air rates, the froth was not particle stabilised. This was evident from the very high water content of the overflowing froth in association with to very high air recoveries. In operating regions where the froth is not particle stabilised such as this, air recovery measurements become unrepresentative as the assumption that the overflowing froth has a low liquid content (Woodburn et al., 1994) becomes invalid. It is interesting that this phenomena was not observed for particle set $A$; this suggests that the froth moves into an entrainment-dominated regime, which is more likely for finer particles.

Over the range of air rates tested, the coarsest particle size distribution (set A) resulted in the lowest air recovery. While this may be linked to the destabilising effect on the froth phase through rupturing of the thin films (Moudgil and Gupta, 1989; Moudgil, 1992; Rahman et al., 2012), it can also be linked to reduced froth mobility, with coarser particles less likely to be recovered by entrainment. Particle sets $B$ and $C$, which have similar mean sizes, demonstrate significantly different air recoveries to each other, particularly at the highest air rate, where particle set $\mathrm{C}$, which has the smaller $d_{80}$, yields the most stable froth. Conversely, at the lowest air rate, it is particle set $B$ that yields the highest air recovery. This suggests that comparatively small variations in particle size distribution can have significant effects on the magnitude of the measured air recovery. It is helpful, however, to consider these results together with physical measurements taken, in order to determine the effect on flotation performance. 


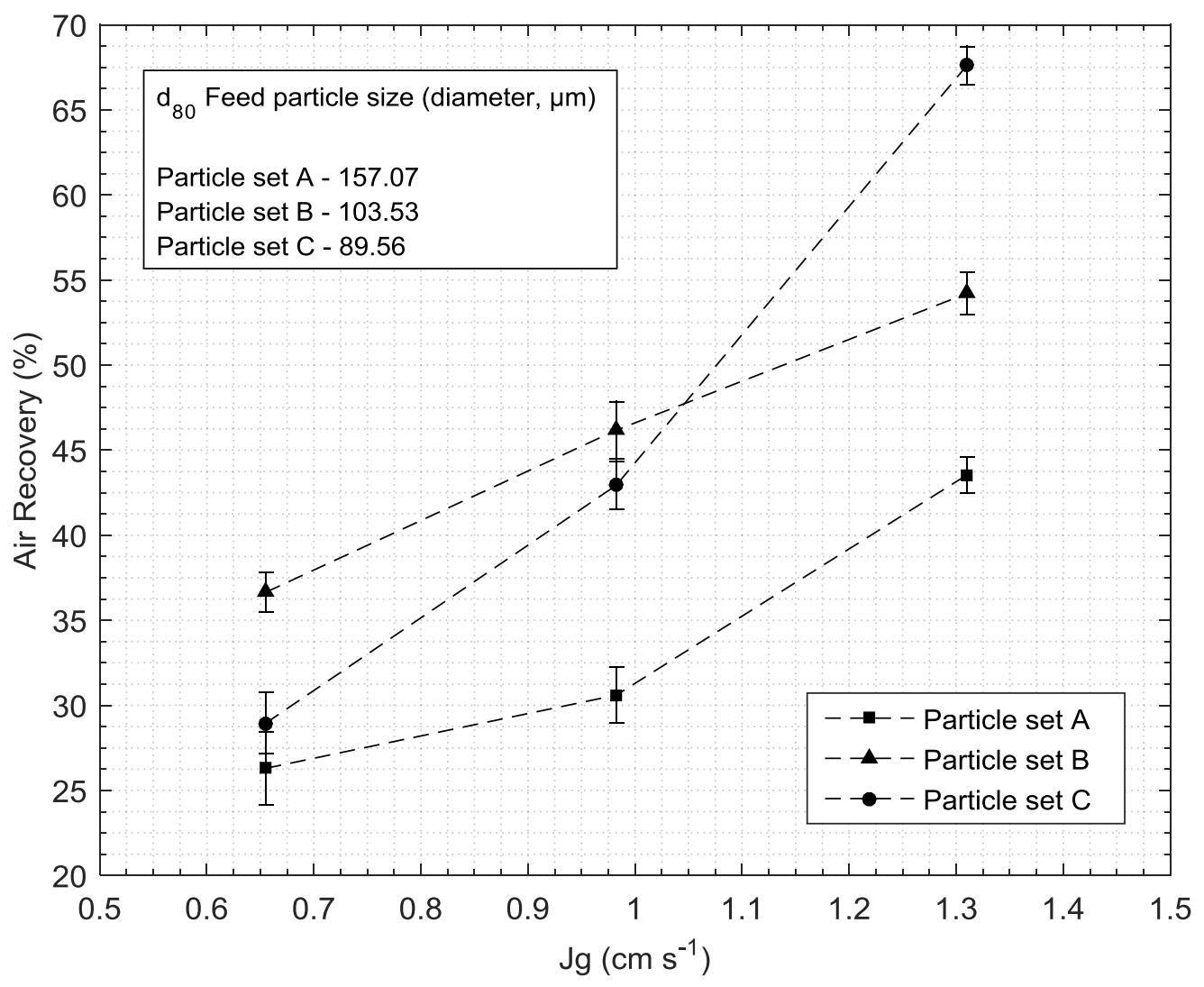

Figure 5 - Air recovery as a function of $\mathrm{Jg}$ for each particle size in the feed, errors given as $95 \%$ confidence intervals.

3.4 Indicative Flotation Performance: Proxies for flotation performance for a single species system

Typical indicators of flotation separation performance are concentrate grade and mineral recovery. As the solid particles in this system comprise a single species (silica), it is not possible to establish the performance of any separation, instead it is necessary to determine proxies of performance quantifiers. For concentrate grade (the proportion of solids reporting to the concentrate that are the mineral or species of interest), it is proposed that solids content of the concentrate is a suitable proxy. A comparison between concentrate grade and solids content for a bank of cells for the same industrial data as given in Figure 4 (b) is given in Figure 6.

Here it can be seen that, in general, the grade and solids content are positively correlated down the bank. Conditions that yield high concentrate grades are typically obtained where recovery of entrained gangue is lower, which corresponds with lower water recoveries and higher solids contents in the concentrate. Down the bank, it can also be seen that there is a feed grade effect, with lower feed grades yielding lower concentrate grades and solids 
contents, suggesting there is an additional liberation effect. Note also that froth depth is not taken into account in these data. While subtleties in the data, such as trends in individual cells and/or with different operating conditions, are lost in Figure 6, the positive correlation suggests that for the single species system, the use of concentrate solids content as a proxy for concentrate grade is appropriate for the comparison of different operating conditions.

The flowrate of solids to the concentrate (mass pull) has been used as an indicator of recovery at operating concentrators (Supomo et al. 2008; Jameson 2010), on the basis that operating conditions that yield higher mass pull also yield higher mineral recovery. This is shown in Figure 7 for the same industrial experimental data as shown previously, where the two measures can be seen to be positively correlated. As with the solids content and concentrate grade, it should be noted that this generalised approach for a bank of cells does neglect subtleties in the trends. Hadler et al. (2010), for example, showed that the mineral recovery increases together with higher mass pull with increasing air rate up to the PAR air rate. At air rates higher than the PAR air rate, the mass pull continued to increase with no corresponding increase in recovery. Similarly, the effects of feed grade and other operating parameters, such as froth depth, are not considered in Figure 7. For the single species system, where selective and non-selective recovery cannot be distinguished, the solids flowrate will give a suitable indicator of recovery.

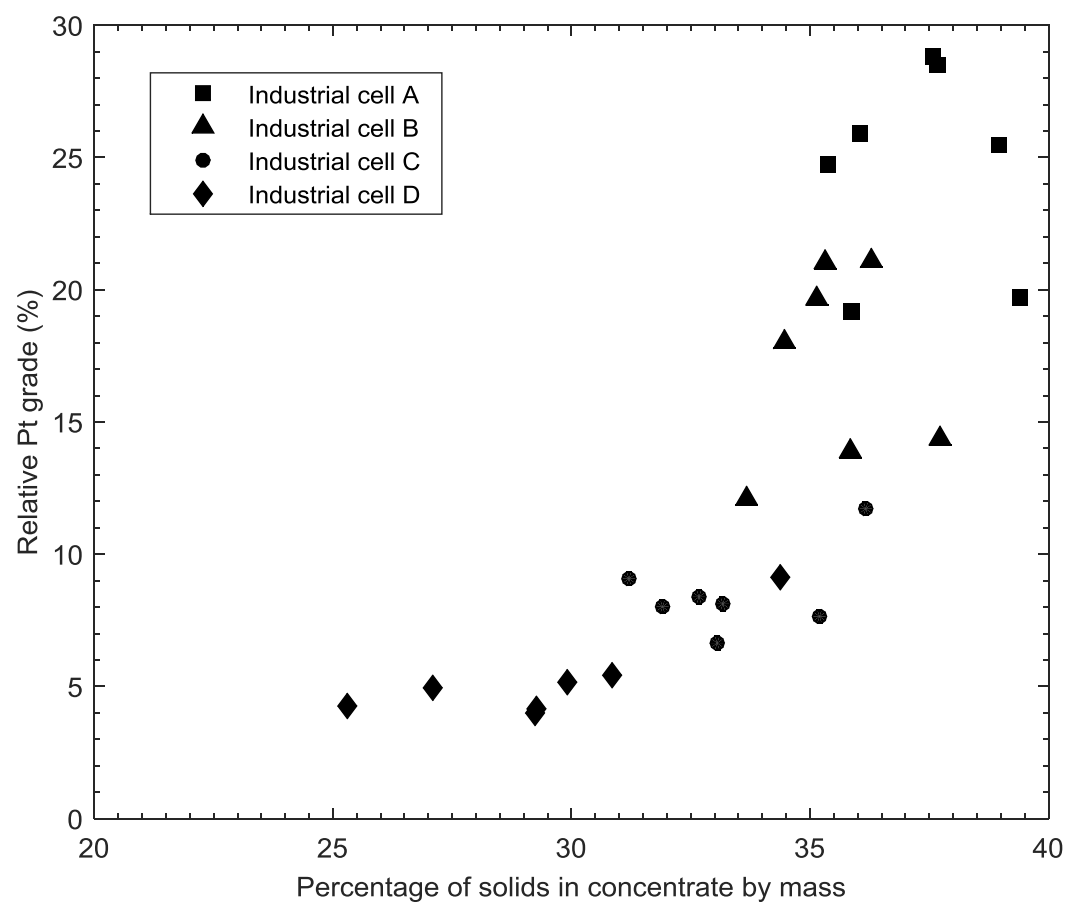

Figure 6 - The relationship between concentrate solids content and grade for a bank of four industrial flotation cells. 


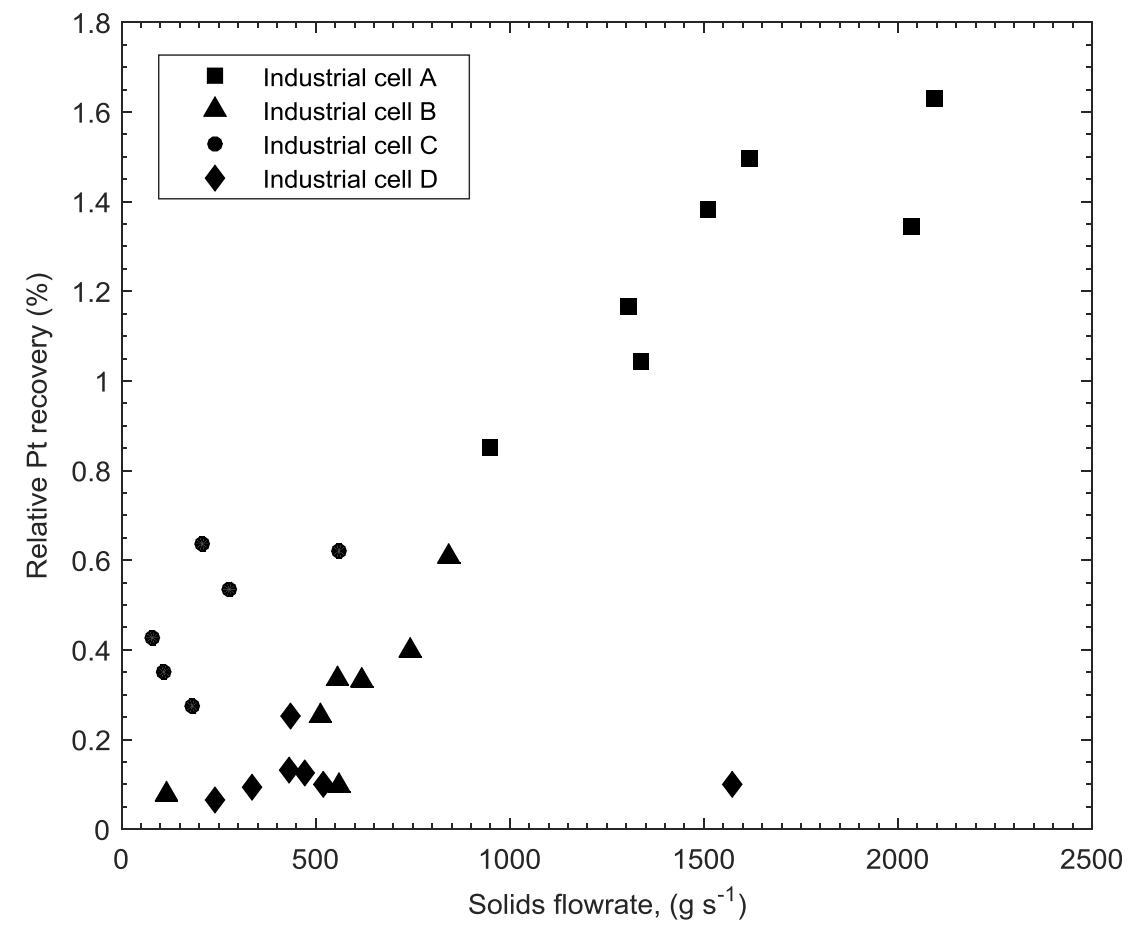

Figure 7 - The relationship between solids flowrate and recovery in a bank of four industrial flotation cells.

The use of concentrate solids content and solids flowrate as proxies for grade and recovery for the laboratory system is shown in Figure 8, where Figure 8(a) shows the indicative 'grade-recovery' curve for particle set A over the range of air rates given in Figure 4(a). It should be noted that air rate increases from the point at the highest solids content to the lowest. As air rate increases, solids content decreases, which is in line with typical flotation responses (e.g. Hadler et al. 2010; Maldonado et al., 2011), while the solids flowrate initially increases, before dropping again at higher air rates. The air rate that yields the highest solids flowrate ('recovery') is the same as yields the peak in air recovery (Figure 4(a)). In comparison, Figure 8(b) and (c) show, respectively, the normalised grade-recovery curve and the solids content-solids flowrate curve for the industrial cell in Figure 4(b). There is good agreement between the shape of the curves from the industrial and laboratory data, however there is a key difference between mineral recovery in Figure 8(b) and solids flowrate Figure $8(\mathrm{c})$. Mineral recovery decreases at air rates above PAR, while solids flowrate continues to increase. At high air rates, the recovery of entrained material and water yields poor quality (i.e. low grade and low solids content) concentrates. This does not lead to an improvement in mineral recovery (Hadler et al., 2010). 

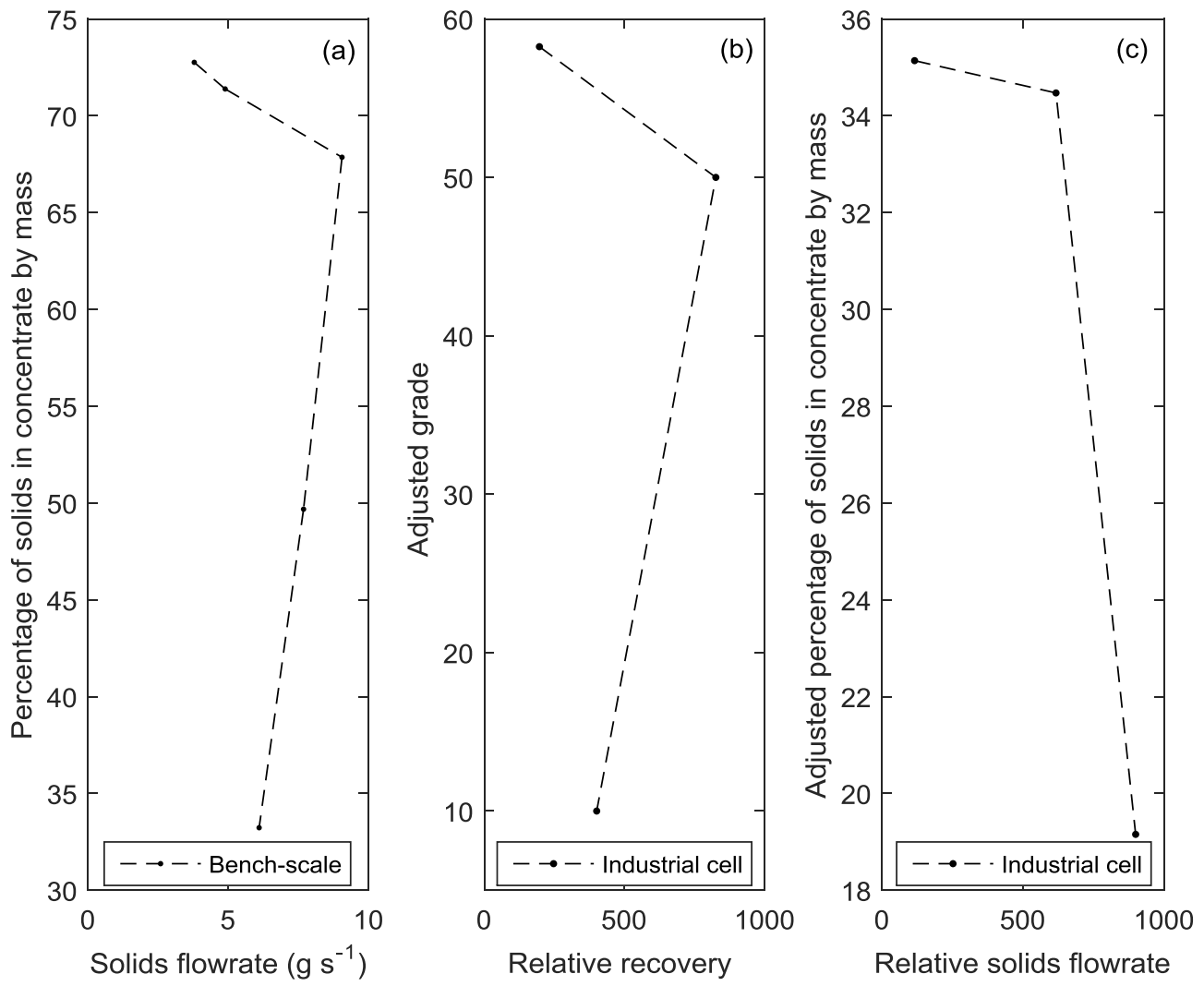

Figure 8 - (a) Solids flowrate with percentage of solids in concentrate for the bench-scale system, compared with an industrial flotation cell grade and recovery (b) and its percentage of solids in concentrate with solids flowrate (c) (Hadler and Cilliers, 2009).

\subsection{The effect of particle size on indicated flotation performance}

The variation in solids content with air rate for the three particle sets is shown in Figure 9. The results show that for all particle sets, the solids content decreases with increasing air rate, a trend observed in flotation systems in which a separation is being carried out. This is linked to the increase in the recovery of entrained material as air rate increases. The large error bars, particularly at the lowest air rate, are due to manual sampling.

Although there is little difference between the concentrate solids contents at the lowest air rate, for the higher air rates, the coarsest particle size distribution $(A)$ results in the highest solids content, which can be linked to the lower air recovery and lower rates of entrainment for coarser particles (Rahman et al., 2012). On the other hand, there is little difference between the solids content for particle sets $B$ and $C$ over any of the air rates, in spite of the higher air recoveries obtained for the finer size distribution $(\mathrm{C})$. The link between particle size and entrainment has been well-documented (Trahar, 1981; Lee et al., 2005; Neethling and Cilliers, 2009). From Table 1, the comparison of the particle size distributions of the three particle sets shows that sets $B$ and $C$ have similar distributions at the fine end $\left(d_{10}\right.$ and 
$d_{50}$ ), while set $B$ shows a significantly larger $d_{80}$. This similarity at the fine end of the distributions suggests that the similarity in 'grade' between the two distributions is caused by similar rates of entrainment of these fine particles.

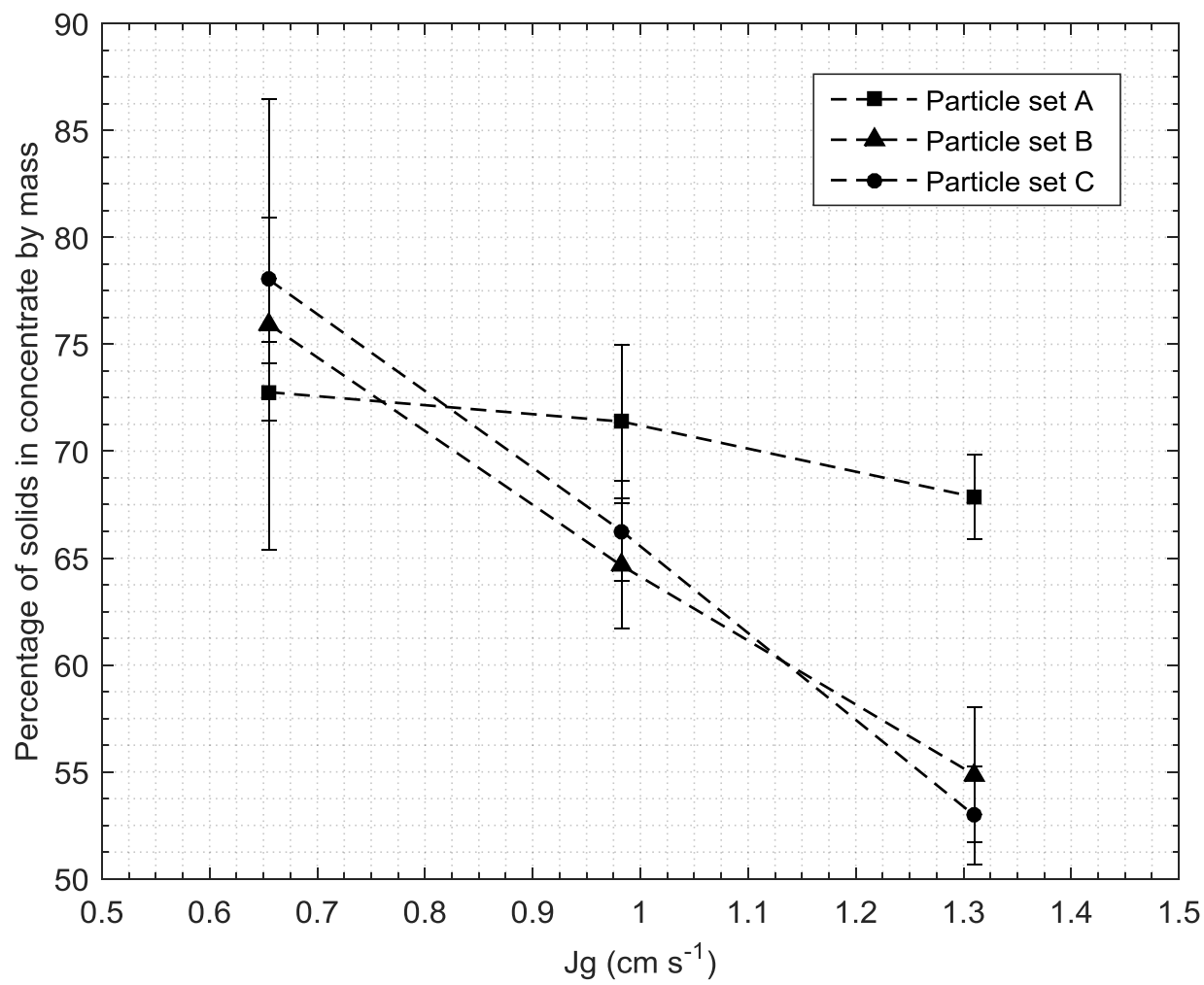

Figure 9 - Percentage of solids in the concentrate by mass with air rate. Errors given as $95 \%$ confidence intervals.

The variation in solids flowrate to concentrate with increasing air rate is given in Figure 10. Here, the solids flowrate, used as an indicator of recovery, increases as cell air rate increases, in line with increases in air recovery shown in Figure 5. Furthermore, the particle set that yields the highest air recovery for a given air rate (i.e. set $B$ for the lowest two air rates and set $C$ for the highest) also yield the highest solids flowrate. This result agrees with the findings of Hadler and Cilliers (2009), Hadler et al. (2010) and Smith et al. (2010). It is also noted that under select operating conditions (i.e. lower air rates), feeds containing coarser particles can result in higher recoveries than those containing finer particles (liberation effects notwithstanding).

In general, the flotation results for this system show that 'grade' drops as air rate increases, while 'recovery' increases. This is in line with findings from industrial cells. Furthermore, the coarsest particles resulted in the lowest air recovery, the highest grade and the lowest recovery. As the proportion of coarse particles in the feed decreased, the air recovery did not increase monotonically, rather a peak in air recovery was observed at lower air rates; higher recovery was also obtained under these conditions. At higher air rates, the finest 
particle size distribution (i.e. smallest $d_{80}$ ) resulted in the highest air recovery and the highest recovery.

These findings show that fine particles can yield more stable overflowing froths, but this is dependent on the air rate. A lower proportion of fine particles (i.e. particle set A) yielded low air recoveries, high grades and low recoveries over all air rates. For a similar mean particle size $\left(d_{50}\right)$, a greater proportion of coarser particles (i.e. $d_{80}$ for particle set $B$ ) resulted in higher froth stability at lower air rates. This demonstrates that small changes in the particle size range can have significant effects on the froth stability, which affects the final flotation performance.

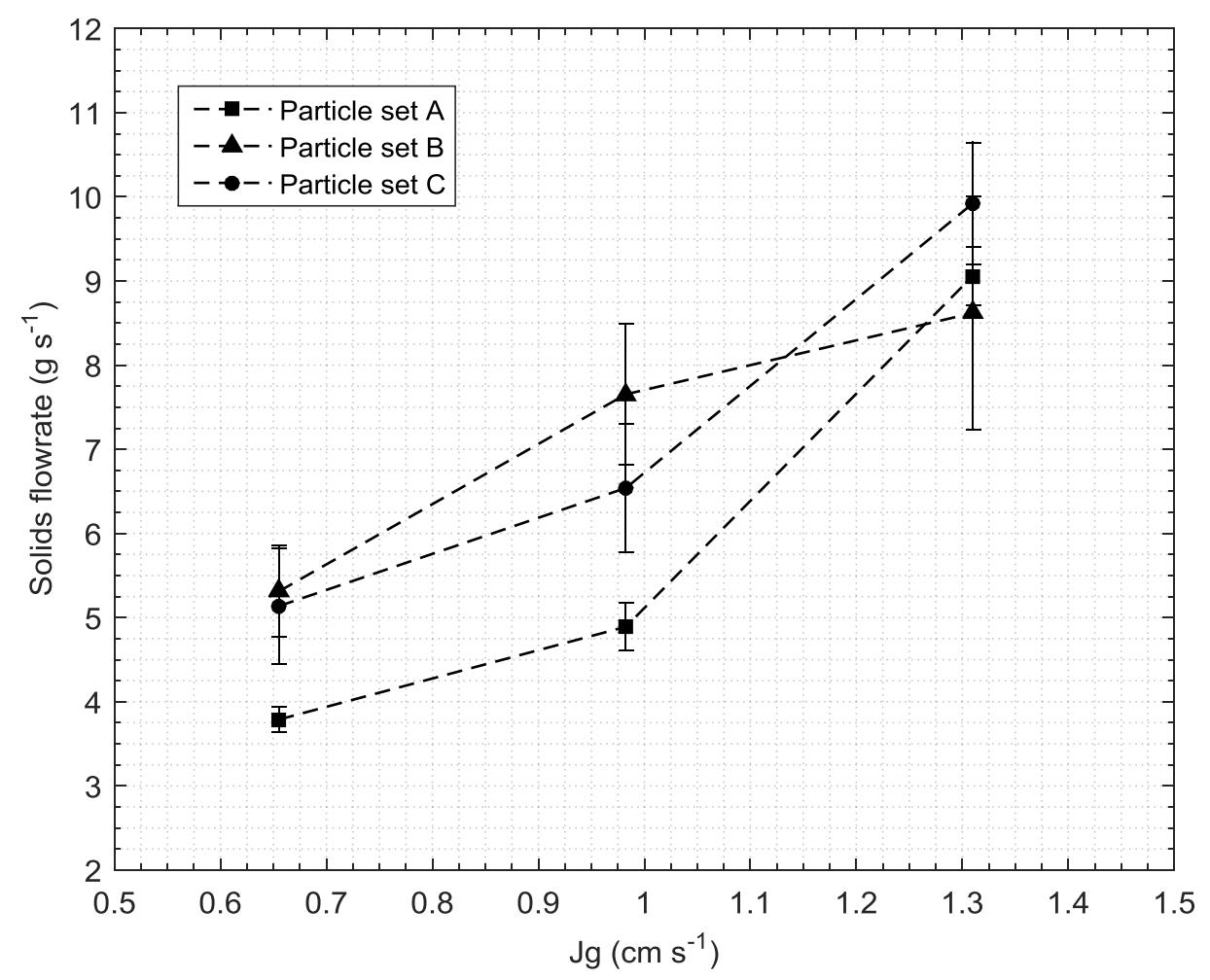

Figure 10 - Solids flowrate in the concentrate with particle size in the feed, for each particle set. Errors given as $95 \%$ confidence intervals.

\section{Conclusions}

Flotation experiments carried out using a continuous bench scale flotation system operating at steady state have provided a better understanding of the effect of particle size distribution on the stability of flotation froths. In particular, the experimental system used in this work has allowed the effects of mineral liberation to be negated by considering a silica-only system. 
This study has shown that the effect of the feed particle size on the stability of flotation froths is not only dependent on the air rate but also highly sensitive to small changes in the particle size distribution. The behaviour of the froth in the laboratory system was shown to be comparable to that of industrial froths, allowing the determination of the effects of particle size distribution, which is otherwise difficult to study at industrial scale. The solids content in the concentrate and the solids recovery in this system were shown to act as adequate indicators of grade and recovery, respectively.

This work has also highlighted the importance of considering the whole size distribution of particles when assessing the effect that its variation has on performance, as even small changes in the particle size distribution produce important changes in air recovery. Among the three particle size classes used, the highest air recovery was obtained for the finest distribution but only at the higher air rate. At lower air rates, the intermediate distribution resulted in the highest air recovery. This dependence on air rate shows that particle size cannot be linked directly to changes in froth stability without also considering operating parameters, such as air rate.

Further, the particle size distribution that yielded the highest air recovery at a given air rate also resulted in the highest recovery. This is an important finding, which supports the use of air recovery for the optimisation and control of industrial flotation cells.

\section{Acknowledgements}

The financial support of Rio Tinto through the Rio Tinto Centre for Advanced Mineral Recovery in this research is gratefully acknowledged.

\section{References}

Aktas, Z., Cilliers, J.J., Banford, A.W., 2008. Dynamic froth stability: Particle size, airflow rate and conditioning time effects. Int. J. Miner. Process. 87, 65-71. doi:10.1016/j.minpro.2008.02.001

Ata, S., 2011. The role of frother on the detachment of particles from bubbles. Miner. Eng. 24, 476-478. doi:10.1016/j.mineng.2010.12.008

Ata, S., Ahmed, N., Jameson, G.J., 2002. Collection of hydrophobic particles in the froth phase. Int. J. Miner. Process. 64, 101-122. doi:10.1016/S0301-7516(01)00066-7

Barbian, N., Hadler, K., Cilliers, J.J., 2006. The froth stability column: Measuring froth stability at an industrial scale. Miner. Eng. 19, 713-718. doi:10.1016/j.mineng.2005.09.021

Brito-Parada, P.R., Cilliers, J.J., 2012. Experimental and numerical studies of laudner configurations in a two-phase flotation system. Miner. Eng. 36-38, 119-125. doi:10.1016/j.mineng.2012.03.009

Cornell, W.L., Wethington, A.M., Holtgrefe, D.C., Sharp, F.H., 1987. Continuous flotation 
testing to recover cobalt from Missouri lead ores.

Costes, J., Couderc, J.P., 1988. Study by laser Doppler anemometry of the turbulent flow induced by a Rushton turbine in a stirred tank: Influence of the size of the units - I. Mean flow and turbulence. Chem. Eng. Sci. 43, 2765-2772. doi:10.1016/00092509(88)80018-6

Crawford, R., Ralston, J., 1988. The influence of particle size and contact angle in mineral flotation. Int. J. Miner. Process. 23, 1-24. doi:10.1016/0301-7516(88)90002-6 begin_of_the_skype_highlighting FREE (88)90002-6end_of_the_skype_highlighting

Derjaguin, B.V., Dukhin, S., 1993. Theory of flotation of small and medium-size particles. Prog. Surf. Sci. 43, 241-266.

Falutsu, M., 1994. Column flotation froth characteristics - stability of the bubble-particle system. Int. J. Miner. Process. 40, 225-243. doi:10.1016/0301-7516(94)90045-0

Gaudin, A.M., Schuhmann, R., Schlechten, A.W., 1942. Flotation Kinetics. II. The Effect of Size on the Behavior of Galena Particles. J. Phys. Chem. 46, 902-910. doi:10.1021/j150422a013

Hadler, K., Cilliers, J.J., 2009. The relationship between the peak in air recovery and flotation bank performance. Miner. Eng. 22, 451-455. doi:10.1016/j.mineng.2008.12.004

Hadler, K., Greyling, M., Plint, N., Cilliers, J.J., 2012. The effect of froth depth on air recovery and flotation performance. Miner. Eng. 36-38, 248-253. doi:10.1016/j.mineng.2012.04.003

Hadler, K., Smith, C.D., Cilliers, J.J., 2010. Recovery vs. mass pull: The link to air recovery. Miner. Eng. 23, 994-1002. doi:10.1016/j.mineng.2010.04.007

Jameson, G.J., 2010. New directions in flotation machine design. Miner. Eng. 23, 835-841. doi:10.1016/j.mineng.2010.04.001

Jameson, G.J., Nguyen, A. V., Ata, S., 2007. The flotation of fine and coarse particles 339372.

Jenne, M., Reuss, M., 1999. A critical assessment on the use of $k-\varepsilon$ turbulence models for simulation of the turbulent liquid flow induced by a Rushton-turbine in baffled stirredtank reactors. Chem. Eng. Sci. 54, 3921-3941. doi:10.1016/S0009-2509(99)00093-7

Johansson, G., Pugh, R.J., 1992. The influence of particle size and hydrophobicity on the stability of mineralized froths. Int. J. Miner. Process. 34, 1-21. doi:10.1016/03017516(92)90012-L

Kaya, M., Laplante, A.R., 1985. Investigation of Batch and Continuous Flotation Kinetics in a Modified Denver Laboratory Cell. Can. Metall. Q. 25, 1-8.

Klassen, V.I., Mokrousov, V.A., 1963. An introduction to the Theory of Flotation. Butterworth, London.

Lee, H.T., Neethling, S.J., Cilliers, J.J., 2005. Particle and liquid dispersion in foams. Colloids Surfaces A Physicochem. Eng. Asp. 263, 320-329. doi:10.1016/j.colsurfa.2004.12.064

Liang, L., Li, Z., Peng, Y., Tan, J., Xie, G., 2015. Influence of coal particles on froth stability and flotation performance. Miner. Eng. 81, 96-102. doi:10.1016/j.mineng.2015.07.004 
Livshits, A., Dudenkov, S.V., 1965. Some factors in flotation froth stability. Int. J. Miner. Process. 1, 367-371.

Maldonado, M., Araya, R., Finch, J., 2011. Optimizing flotation bank performance by recovery profiling. Miner. Eng. 24, 939-943. doi:10.1016/j.mineng.2011.04.014

Moudgil, B.M., 1992. Enhanced Recovery of Coarse Particles During Phosphate Flotation, Final Report to Florida Institute of Phosphate Research.

Moudgil, B.M., Gupta, D., 1989. Flotation of coarse particles, in: Advances in Coal and Mineral Processing Using Flotation. pp. 164-168.

National Instruments, 2016. labVIEW [WWW Document]. URL http://www.ni.com/labview/

Neethling, S.J., Cilliers, J.J., 2009. The entrainment factor in froth flotation: Model for particle size and other operating parameter effects. Int. J. Miner. Process. 93, 141-148. doi:10.1016/j.minpro.2009.07.004

Rahman, R.M., Ata, S., Jameson, G.J., 2012. The effect of flotation variables on the recovery of different particle size fractions in the froth and the pulp. Int. J. Miner. Process. 106109, 70-77. doi:10.1016/j.minpro.2012.03.001

Shean B., Hadler K., Cllliers J.J., 2017. A flotation control system to optimise performance using peak air recovery. Chem. Eng. Res. Des., 117, 57-65. doi:10.1016/j.cherd.2016.10.021

Smith, C.D., Hadler, K., Cilliers, J.J., 2010. Flotation bank air addition and distribution for optimal performance. Miner. Eng. 23, 1023-1029. doi:10.1016/j.mineng.2010.05.003

Supomo, A., Yap, E., Zheng, X., Banini, G., Mosher, J., Partanen, A., 2008. PT Freeport Indonesia's mass-pull control strategy for rougher flotation. Miner. Eng. 21, 808-816. doi:10.1016/j.mineng.2008.07.002

Tao, D., Luttrell, G.H., Yoon, R.-H., 2000. A parametric study of froth stability and its effect on column flotation of fine particles. Int. J. Miner. Process. 59, 25-43. doi:10.1016/S0301-7516(99)00033-2

Tasdemir, A., Tasdemir, T., Oteyaka, B., Taşdemir, A., Taşdemir, T., Öteyaka, B., 2007. The effect of particle size and some operating parameters in the separation tank and the downcomer on the Jameson cell recovery. Miner. Eng. 20, 1331-1336. doi:10.1016/j.mineng.2007.08.007

Trahar, W.J., 1981. A rational interpretation of the role of particle size in flotation. Int. J. Miner. Process. 8, 289-327. doi:10.1016/0301-7516(81)90019-3

Vera, M., Mathe, Z., Franzidis, J.-P., Harris, M., Manlapig, E., O'Connor, C., 2002. The modelling of froth zone recovery in batch and continuously operated laboratory flotation cells. Int. J. Miner. Process. 64, 135-151. doi:10.1016/S0301-7516(01)00068-0

Welsby S.D.D., Vianna S.M.S.M, J.-P. Franzidis., 2010. A continuous pilot-scale flotation rig for the systematic study of flotation variables. Miner. Eng., 23, 826-829. doi: 10.1016/j.mineng.2010.05.014

Woodburn E.T., Austin L.G., Stockton J.B., 1994. Froth based flotation kinetic model. Chem. Eng. Res. Des. 72, 211-226.

Yianatos, J., Contreras, F., Díaz, F., Villanueva, A., 2009. Direct measurement of 
entrainment in large flotation cells. Powder Technol. 189, 42-47. doi:10.1016/j.powtec.2008.05.013

Zheng, X., Johnson, N.W., Franzidis, J.-P., 2006. Modelling of entrainment in industrial flotation cells: Water recovery and degree of entrainment. Miner. Eng. 19, 1191-1203. doi:10.1016/j.mineng.2005.11.005 